THE influence of an anti-allergic agent, suplatast tosilate (IPD-1151T; ( \pm )-[2-[4-(3-ethoxy-2-hydroxypropoxy)phenyl-carbamoyl]-ethyl] dimethylsulfonium p-toluen esulfonate) on allergic bronchoconstriction induced by allergen and methacholine (MCh) were examined in mice. BALB/c mice were sensitized by intraperitoneal injection of dinitrophenylatedkeyhole limpet hemocyan in (DNP-KLH) mixed with $\mathrm{Al}(\mathrm{OH})_{3}$ (DNP-KLH). IPD-1151T was administered orally once a day for either 5 or 14 days in doses of 10 , 30 or $100 \mathrm{mg} / \mathrm{kg}$. Bronchoconstriction was measured $24 \mathrm{~h}$ after the final drug administration. IPD-1151T inhibited both antigen- and MCh-mediated bronchoconstriction in actively sensitized mice. The inhibition induced was closely related to the dose and frequency of oral adm in is tration of the agent. We also examined the effect of IPD-1151T on IgE production in response to DNP-KLH immunization. IPD-1151T inhibited dose-dependently both total and specific $\operatorname{IgE}$ concentrations in serum prepared from mice 15 days after immunization. These results strongly indicate that IPD-1151T inhibits IgE production in vivo and results in attenuating effect on bronchoconstriction.

Key words: Anti-allergic agent, Allergen, Bronchoconstriction, IgE, IL-4, IPD-1151T, Methacholine, Mouse, Suppression

\section{The inhibitory effect of anti-allergic agent suplatast tosilate (IPD-1151T) on methacholine- and allergen-induced bronchoconstriction in sensitized mice}

\author{
Kazuhito Asano ${ }^{1, C A}$, Tetsuya Mizutani ${ }^{2}$, \\ Toshikazu Shimane ${ }^{2}$, Masataka Hisano ${ }^{1}$, \\ Tadashi Hisamitsu ${ }^{1}$ and Harumi Suzaki ${ }^{2}$
}

${ }^{1}$ Department of Physiology and ${ }^{2}$ Department of Otolaryngology, School of Medicine, Showa University, Shinagawa-ku, Tokyo 142-8555, Japan

${ }^{\mathrm{CA}}$ Corresponding Author

Department of Physiology, School of Medicine, Show a University, 1-5-8 Hatanodai, Shinagaw a-ku, Tokyo 142-8555, Japan

Tel: +81337848110

Fax: +81337845368

E-mail: asakazu@med.showa-u.dc.jp

\section{Introduction}

Bronchial hyper-responsiveness (BHR) is an important feature of bronchial asthma and the degree of BHR is believed to reflect the severity of the disease. ${ }^{1,2}$ The ultimate task of asthma treatment is the relief of symptoms to permit a normal style of life. The main measures to achieve this focus on the decrease of airflow obstruction and the shift of BHR towards a normal range. ${ }^{3,4}$ To accomplish these objectives, several types of anti-allergic drugs with bronchodilating activity have been developed and are used in the treatment and management of bronchial asthma. Although the mechanisms of BHR are not fully understood, there is an established concept that $\operatorname{IgE}$ is a prime mediator in development of BHR, especially allergen-induced BHR. ${ }^{4-7}$ That is, $\operatorname{IgE}$ antibodies bind to specific membrane receptors on mast cells and basophils. Combination of specific cell-bound antibody with antigen triggers a series of events leading to release of vasoactive amines and other pharmacologically active substances responsible for clinical manifestation of $\mathrm{BHR}^{8}{ }^{8}$ Recently IgE antibody receptors have also been demonstrated on a subpopulation of eosinophils and platelets, among others. ${ }^{9}$ Binding of $\operatorname{IgE}$ antibody to receptors on these cells results in the enhancement of their function and the release of various chemical mediators responsible for allergic inflammation. ${ }^{10-12}$ From these standpoints, drugs specifically inhibiting IgE antibody formation would be highly feasible for the therapy of allergic patients. However, such drugs are not available nowadays.

During immunopharmacological studies on dimethylsulfonium compounds, it is found that suplatast tosilate (IPD-1151T) suppresses Th2 type cytokine production, $\operatorname{IgE}$ synthesis, and chemical mediator release from mast cells in the mouse and guinea pig models of asthma. ${ }^{13-17}$ IPD-1151T has also been reported to suppress the production of Th2 type cytokines and IgE by human peripheral blood leukocytes when the cells were obtained from asthmatic patients and cultured with specific antigens in the presence of the agent. ${ }^{18,19}$ Furthermore, it is observed that oral administration of IPD-1151T could attenuate eosinophilia and hyperimmunoglobulinemia $\mathrm{E}$ in patients with Kimura's disease. ${ }^{20}$ From these reports, there is a possibility that IPD-1151T may be a new antiallergic drug that could prove useful for treatment and prevention of asthma. However, there are no reports of the influence of IPD-1151T on bronchoconstriction. 


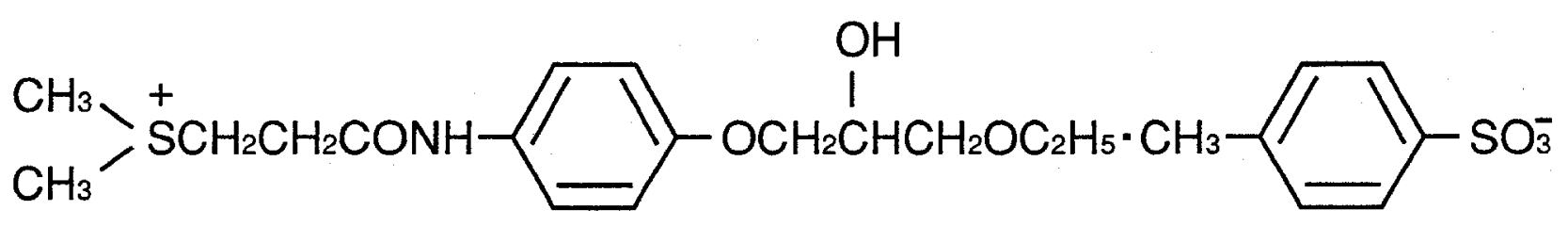

FIG. 1. Chemical structure of suplatast tosilate (IPD-1151T).

In this study, therefore, we investigated the effect of IPD-1151T on allergic airway hyper-responsiveness induced by exposure of keyhole lympet hemocyanin (KLH)-sensitized mice to repetitive antigen and to methacholine (MCh).

\section{Materials and methods}

\section{Animals}

Specific pathogen-free, normal and athymic BALB/c mice were purchased from Charles River Japan Inc., Atsugi, Japan. They were all male and 5 weeks of age at the start of the experiments. Conventional Wistar male rats were obtained from Nippon Bio-supply Center (Tokyo, Japan). All animal ex perimental procedures used in this study were approved by the Showa University Animal Ethics Committee, and carried out in accordance with the guidelines of the Physiological Society of Japan.

\section{Agent}

IPD-1151T (Fig. 1) was kindly supplied from Taiho Pharmaceutical Co. Ltd., Tokyo, Japan, as a preservative-free pure powder. The agent was dissolved in distilled water at $5 \mathrm{mg} / \mathrm{ml}$ just before use.

\section{Antigens}

KLH (Sigma Chemical Co. Ltd, St Louis, MO, USA) was coupled with dinitrobenzen-sulfonic acid sodium salt (DNP) (Tokyo Kasei Corp., Tokyo, Japan) according to the methods of Lee and Sehon. ${ }^{21}$ Bovine serum albumin (BSA) (Sigma Chemical Co. Ltd.) was also coupled with DNP in a similar manner. They were abbreviated DNP-KLH and DNP-BSA, respectively.

\section{Preparation of cell suspension}

To prepare spleen cell suspension, normal BALB/c mice were killed by intraperitoneal injection with pentobarbital sodium (Abbott Lab., North Chicago, IL, USA) at a dose of $60 \mathrm{mg} / \mathrm{kg}$. The spleen was removed, pooled from five mice and stored at $4^{\circ} \mathrm{C}$ until processed. The organs were pressed through a 60-gauge steel mesh and then filtered through a 200-gauge steel mesh to remove debris and cell clumps. The cells were washed five times with RPMI1640 medium (Flow Lab., Irvine, Scotland) supplemented with $10 \%$ fetal calf serum (FCS) (Flow Lab., North Ride, Australia), $5 \times 10^{-5} \mathrm{M} 2$ mercaptoethanol, $10 \mathrm{mM} \quad \mathrm{N}-2$-hydroxyethylpipe razine-N'-2-ethanesulfonic acid, $100 \mathrm{U} / \mathrm{ml}$ penicillin and $100 \mu \mathrm{g} / \mathrm{ml}$ streptomycin (RPMI-FCS) and resuspended in the fresh medium at a concentration of $5 \times 10^{6}$ cells $/ \mathrm{ml}$. Spleen cell suspensions were also prepared from five athymic nude mice in a similar manner.

\section{Cell culture}

Spleen cell suspension $(100 \mu \mathrm{l}) \mathrm{w}$ as introduced into each well of 96-well flat-bottomed microculture plates (Nunc Intermed, Denmark), which contained $10 \mu \mathrm{g} / \mathrm{ml}$ of either lippoporisaccharide (LPS) or concanavalin A (Con A). The plats were maintained for $48 \mathrm{~h}$ in a humidified atmosphere with $5 \% \mathrm{CO}_{2}$ at $37^{\circ} \mathrm{C}$. Cell activation was assessed by adding $1 \mu \mathrm{Ci} / \mathrm{well}$ of ${ }^{3} \mathrm{H}$-thymidine (Amersham International plc, Bucks, UK) for the final $6 \mathrm{~h}$ of culture. The results were expressed as mean $\mathrm{cpm} \pm \mathrm{SD}$ of triplicate cultures. To prepare culture supernatant, $1 \mathrm{ml}$ of spleen cell suspension was cultured in 24-well culture plates (Nunc Intermed) containing $1 \mathrm{ml}$ of $10 \mu \mathrm{g} / \mathrm{ml}$ of Con A. After $24 \mathrm{~h}$, culture supernatants were obtained after pelleting the cells by centrifugation at $2000 \mathrm{~g}$ for $10 \mathrm{~min}$ at $4^{\circ} \mathrm{C}$. The supernatant was stored at $-40^{\circ} \mathrm{C}$ until used.

\section{Immunization}

Mice were immunized by intraperitoneal injection with $5 \mu \mathrm{g} / \mathrm{ml}$ of DNP-KLH mixed with $2 \mathrm{mg}$ of $\mathrm{Al}(\mathrm{OH})_{3}$ (Wako Pure Chemical Ind., Osaka, Japan) in a to tal volume of $0.5 \mathrm{ml}$ of saline.

\section{Drug administration}

Mice were orally administered with either 10,30 or $100 \mathrm{mg} / \mathrm{kg}$ of IPD-1151T in a volume not exceeding $0.5 \mathrm{ml}$. Administration was performed once a day on the following schedules: one group of mice were treated for 5 days from Day 9 of sensitization and the others for 14 days from Day 0. Control mice received distilled water only in a volume not exceeding $0.5 \mathrm{ml}$. 


\section{Assay for IgE antibody}

Mice were bled by cardiac puncture. Serum was isolated by centrifugation and stored at $-40^{\circ} \mathrm{C}$ until used. Total concentration of $\operatorname{IgE}$ antibody in serum was assayed by commercially prepared mouse $\operatorname{IgE}$ enzyme-linked immunosorbent assay (ELISA) test kit (Yamasa Shoyu Co. Ltd, Chiba, Japan) according to the manufacturer's recommended procedure. Briefly, wells of a 96-well microtiter plate coated with antimouse IgE monoclonal antibody received $100 \mu \mathrm{l}$ of test samples and of standards, separately. After incubation at $25^{\circ} \mathrm{C}$ for $30 \mathrm{~min}$, the wells were washed 5 times with washing buffer. Antimouse IgE enzyme conjugate $(100 \mu \mathrm{l} / \mathrm{well})$ was then introduced into each well and further incubated for $30 \mathrm{~min}$ at $25^{\circ} \mathrm{C}$. After washing, $200 \mu \mathrm{l}$ of substrate, te tramethylbenzidine, was dispensed, and the reaction proceeded at $25^{\circ} \mathrm{C}$ for $15 \mathrm{~min}$. Absorbance at $450 \mathrm{~nm}$ was determined with an ELISA reader (MRP A4i) (Tosoh Co. Ltd, Tokyo, Japan) after adding $50 \mu \mathrm{l}$ of $2 \mathrm{~N} \mathrm{HCl}$. The ELISA was performed in duplicate and mean absorbance was obtained. Serum antibody concentrations were calculated from standard curve and the results were expressed as mean $\mathrm{ng} / \mathrm{ml} \pm \mathrm{SE}$ of five individual mice. The concentration of DNP-specific $\operatorname{IgE}$ antibody in serum was assayed by passive cutaneous anaphylax is (PCA) in Wistar rats. An intradermal injection of $0.1 \mathrm{ml}$ of serum dilutions was given on the shaved back of rats. Sensitized rats were challenged by $1 \mathrm{mg}$ of DNPBSA in $1 \mathrm{ml}$ of $0.5 \%$ Evans blue dye. Reciprocals of the highest dilution were recorded as the titer of the specific IgE antibody. The results were expressed as the mean PCA titer \pm SE of five individual samples.

\section{Assay for IL-4}

IL 4 contents in culture supernatants was assayed by the commercially available mouse IL-4 ELISA kit (GENZYME TECHNE Corp., Minneapolis, MN, USA) according to the manufacturer's recommendation. The ELISA was done in duplicate and the results were expressed as mean $\mathrm{pg} / \mathrm{ml} \pm \mathrm{SE}$ of five individual mice.

\section{Measurement of airway reactivity}

Twenty-four hours after the final drug administration, mice were anesthetized with intraperitoneal injection of $1.8 \mathrm{mg} / \mathrm{kg}$ body weight of pentobarbital sodium (Abbott Lab.). When an appropriate plane of anesthesia was induced, the trachea was cannulated and connected to a constant-volume respirator for small animals (SN-480-3; Shinano Seisakusho, Tokyo, Japan) that provided ventilation at a tidal volume of $0.5 \mathrm{ml} / 100 \mathrm{~g}$ body weight and a rate of 60 strokes/ min. ${ }^{21}$ Under these conditions, we found that arterial oxygen tension of the mice was kept between 70 and
80 torr as measured with a transcutaneous oxygen tension meter (OXV-7101) (Nihon Koden Co. Ltd, Tokyo, Japan). The flow at the outlet of the intratracheal cannula was measured using a differential transducer (TP-602) (Nihon Koden Co. Ltd). One end of the differential pressure was connected to the outlet of the tracheal cannula, the other end being exposed to atmospheric pressure. The respiratory resistance was determined by the method of Konzett and Rossler ${ }^{22}$ from transpulmonary pressure, airflow and respiratory volume measures. Airway responses to $\mathrm{KLH}$ were measured by intravenous administration of $500 \mu \mathrm{g} / \mathrm{ml}$ of $\mathrm{KLH}$ in a volume of $0.1 \mathrm{ml}^{21}$ In the case of examining the influence of a bronchoconstrictor agonist on airway responses, mice were injected intravenously with increasing quantities of MCh $\left(10^{-6} \mathrm{M}\right.$ to $\left.10^{-2} \mathrm{M}\right)$ in a volume of $0.1 \mathrm{ml}$. The results were expressed as mean volume $(\mathrm{ml})$ of air overflow \pm SE of five mice.

\section{Statistics}

Statistical significance was determined by MannWhitney $U$-test.

\section{Results}

\section{Influence of IPD-1151T on airway hyper-responsiveness}

The first set of experiments was designed to examine the influence of IPD-1151T on airway hyper-responsiveness. To do this, we examined firstly the minimum concentration of $\mathrm{MCh}$ that can cause significant

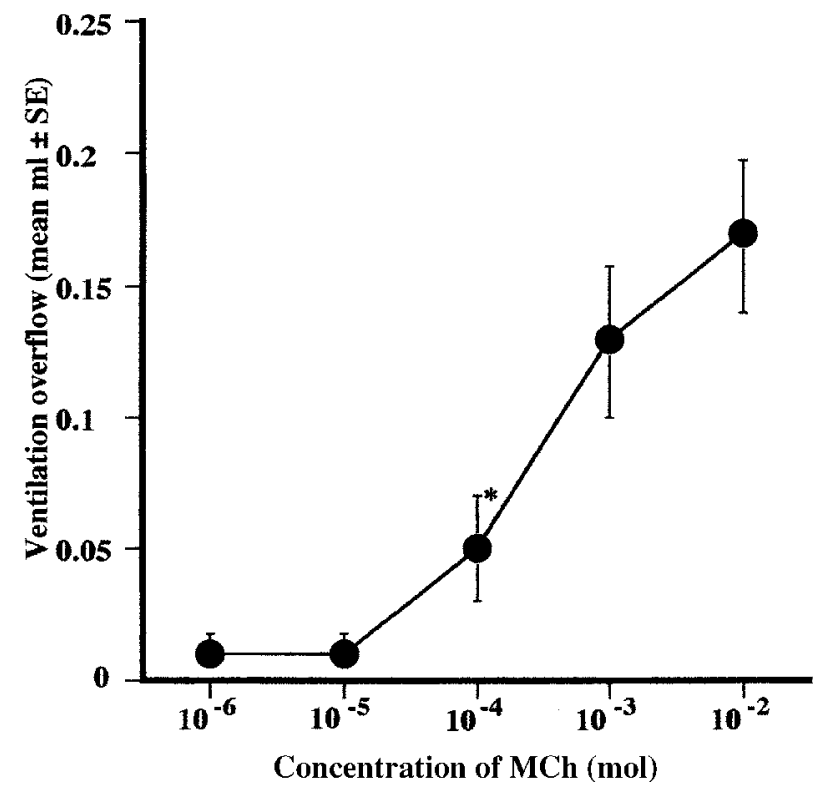

FIG. 2. Influence of MCh on bronchial responsiveness in nonsensitized mice. Each data item is the mean \pm SE of five mice. 


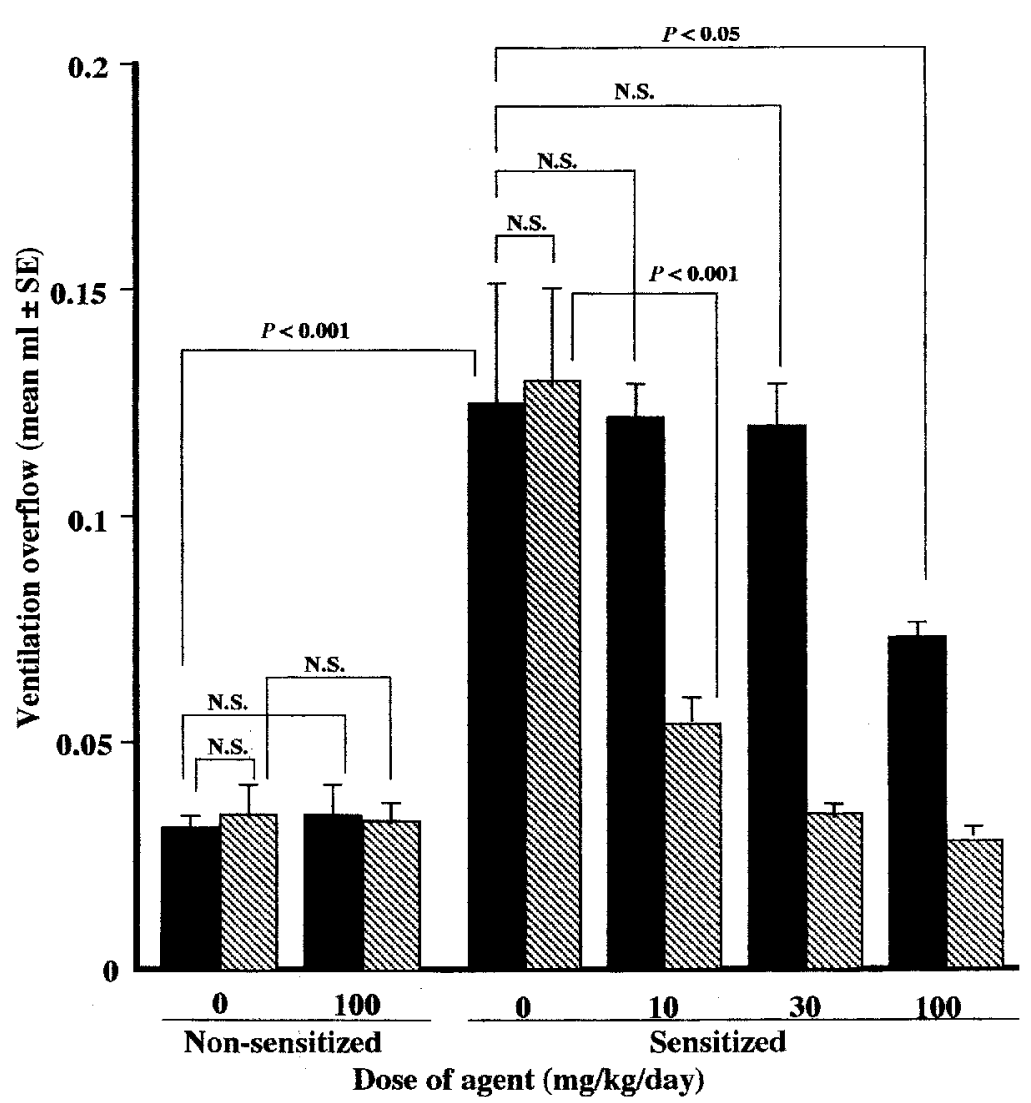

FIG. 3. Influence of suplatast tosilate (IPD-1151T) on MCh-mediated allergic bronchoconstriction in actively sensitized BALB/c mice. Mice were sensitized by intraperitoneal injection with DNP-KLH. The mice were administered orally with IPD-1151T for either 5 (starting on Day 9) ( $\mathbf{\square}$ ) or 14 (starting on Day 0) ( injected intravenously were measured on Day 15, $24 \mathrm{~h}$ after the final drug administration. This is one of two different experiments which gave reproducible results. N.S., Not significant.

bronchoconstriction in non-sensitized mice. The data are shown in Fig. 2. Although low doses of MCh $\left(10^{-6} \mathrm{M}\right.$ and $\left.10^{-5} \mathrm{M}\right)$ scarcely affected airway responses, significant $(P<0.05)$ increase in airway overflow was observed when mice were injected intravenously with $10^{-4} \mathrm{M}$ MCh. The next experiments were designed to examine the influence of oral administration of IPD-1151T on MCh-induced bronchoconstriction in DNP-KLH-sensitized mice. As shown in Fig. 3, intravenous administration of $10^{-4} \mathrm{M} \mathrm{MCh}$ into sensitized mice caused a significant increase in airway hyper-responsiveness as compared with non-sensitized control $(P<0.001)$. Oral administration of IPD$1151 \mathrm{~T}$ inhibited MCh-induced increase in airway responses. The minimum effective dose in 5-day treatment $w$ as $100 \mathrm{mg} / \mathrm{kg}$ and that in 14 -day treatment was $10 \mathrm{mg} / \mathrm{kg}$. The influence of IPD-1151T on antigen-induced allergic airway responses is show $\mathrm{n}$ in Fig. 4. KLH in sensitized mice caused a strong allergic bronchoconstriction as compared with non-sensitized control $(P<0.001)$. Oral administration of IPD-1151T inhibited allergic bronchoconstriction in a dosedependent fashion: as dose and frequency of administration were increased, volume of air overflow gradually decreased (Fig. 4).

\section{Influence of IPD-1151T on in vivo IgE production}

$\mathrm{BALB} / \mathrm{c}$ mice were sensitized intraperitoneally $w$ ith DNP-KLH. Immune serum was obtained from five individual mice $7,10,14,17,21$ and 25 days after sensitization. Non-immune serum was also obtained from age-matched, non-sensitized mice. As show $\mathrm{n}$ in Fig. $5 \mathrm{~A}$, total $\operatorname{IgE}$ concentration in immune serum gradually increased, peaked on Day 14 and declined thereafter from Days 17 to 25. Changes in the levels of DNP-specific IgE antibody showed a similar pattern to that observed in total $\operatorname{IgE}$ concentration: the specific antibody was first detected on Day 7, peaked on Day 14 and declined control levels from Day 17, but sustained on Day 25 (Fig. 5B). The influence of oral administration of IPD-1151T on total and specific IgE concentration in serum prepared from mice sensitized with DNP-KLH is shown in Fig. 6. Oral administration of IPD-1151T, starting on Day 9 of sensitization, significantly inhibited both total and specific $\operatorname{IgE}$ concentration in serum obtained 15 days after sensitization $(P<0.05$; Fig. 6$)$. This inhibitory action of IPD$1151 \mathrm{~T}$ on was further strengthened when administration of agent was started on Day 0 of sensitization (Fig. 6). 


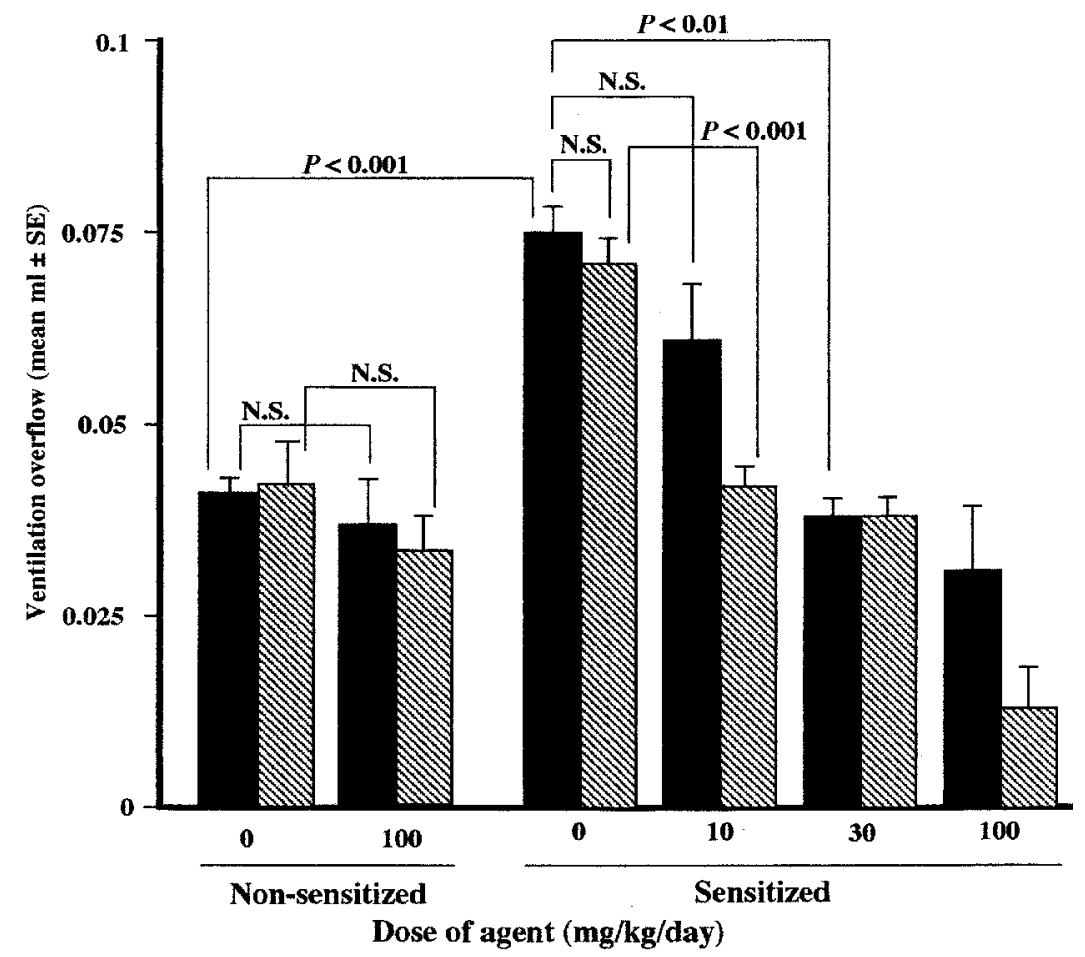

FIG. 4. Influence of suplatast tosilate (IPD-1151T) on bronchoconstriction induced by allergen in actively sensitized BALB/C mice. Mice were sensitized by intraperitoneal injection with DNP-KLH. The mice were administered orally with IPD-1151T for either 5 (starting on Day 9) ( $\mathbf{\square}$ ) or 14 (starting on Day 0 ) (W) days from the day of sensitization. Airway responses to $500 \mu \mathrm{g}$ of $\mathrm{KLH}$ injected intravenously were measured on Day 15, $24 \mathrm{~h}$ after the final drug administration. This is one of two different experiments which gave reproducible results

Influence of IPD-1151T on in vitro lymphocyte proliferative response and interleukin (IL)-4 production

Influence of IPD-1151T on proliferative activities of spleen cells in response to mitogenic stimulation is show $\mathrm{n}$ in Table 1. IPD-1151 T inhibited cell prolifera- tion in dose-dependent manner when the cells were prepared from nude mice and stimulated with LPS in vitro. How ever, IPD-1151T could not suppress T cell mitogen (Con A)-induced proliferative response of spleen cells prepared from normal mice even when the cells were cultured in the presence of $100 \mu \mathrm{g} / \mathrm{ml}$

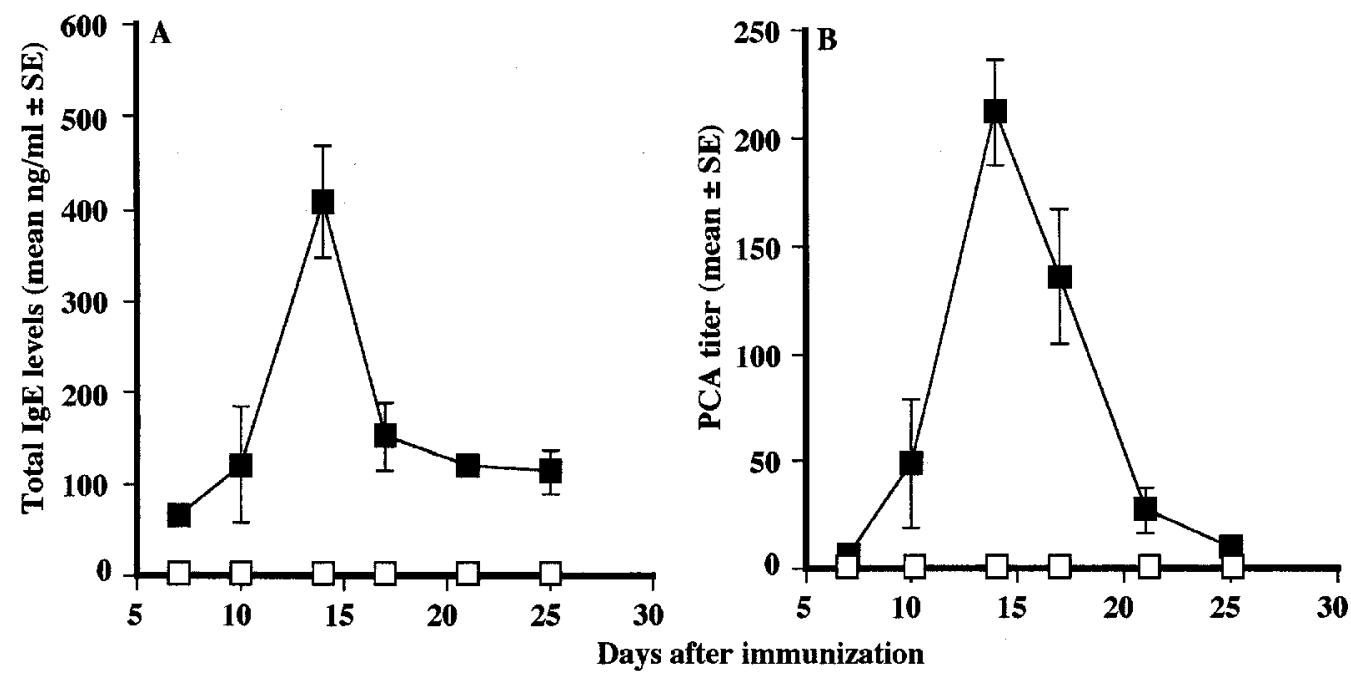

FIG. 5. Changes in total (A) and specific (B) IgE concentrations in serum prepared from BALB/c mice sensitized with DNP-KLH. The mice were injected intraperitoneally with $5 \mu \mathrm{g}$ of DNP-KLH mixed with $\mathrm{Al}(\mathrm{OH})_{3}$ and serum was prepared from five individual mice. Each data item is the mean \pm SE of one of three different experiments which gave reproducible results. ( $\square$ ) Non-sensitized mice; (ם) sensitized mice. 


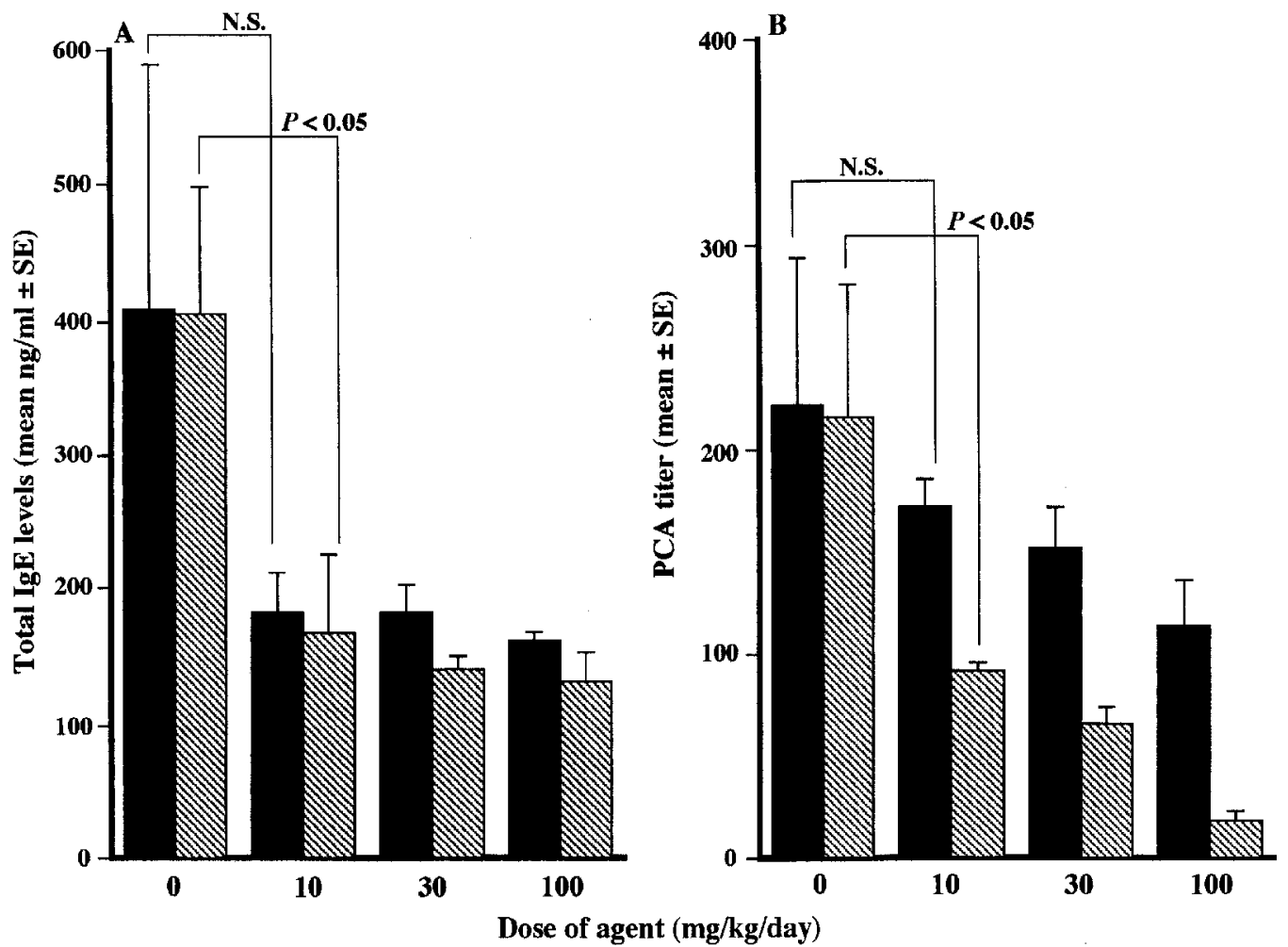

FIG. 6. Influence of IPD-1151T on total (A) and specific (B) IgE concentrations in serum prepared from BALB/c mice sensitized with DNP-KLH. All mice were injected intraperitoneally with $5 \mu \mathrm{g}$ of DNP-KLH mixed with $\mathrm{Al}(\mathrm{OH})_{3}$. The mice were administered orally with IPD-1151T for either 5 (starting on Day 9) (ם) or 14 (starting on Day 0) ( was prepared from five individual mice on Day $15,24 \mathrm{~h}$ after final drug administration.

of the agent. IL-4 production by spleen cells in response to Con A stimulation in vitro was significantly inhibited by IPD-1151T. This inhibitory effect on IL-4 production was dose-dependent and first noted at a concentration of as little as $5 \mu \mathrm{g} / \mathrm{ml}$ (Table 2).

\section{Discussion}

The present study shows that IPD-1151T inhibits MCh-induced increase in airway responses in pre-

Table 1. Influence of IPD-1151T on blastic activity of spleen cells in response to mitogenic stimulation ${ }^{\mathrm{a}}$

\begin{tabular}{lcc}
\hline $\begin{array}{l}\text { Dose of agent } \\
(\mu \mathrm{g} / \mathrm{ml})\end{array}$ & \multicolumn{2}{c}{ Blastic activity (mean $\left.\mathrm{cpm} \times 10^{3} \pm \mathrm{SE}\right)$} \\
\cline { 2 - 3 } & $\begin{array}{c}\text { Nude mice } \\
\text { (LPS stimulation) }\end{array}$ & $\begin{array}{c}\text { Normal mice } \\
\text { (Con A stimulation) }\end{array}$ \\
\hline 0 & $25.5 \pm 0.5$ & $79.6 \pm 1.3$ \\
5 & $16.5 \pm 2.0$ & $85.0 \pm 5.3$ \\
10 & $14.3 \pm 0.2$ & $71.9 \pm 14.7$ \\
50 & $9.4 \pm 0.2$ & $76.7 \pm 1.6$ \\
100 & $6.4 \pm 0.1$ & $82.2 \pm 2.2$ \\
\hline
\end{tabular}

a Spleen cells were prepared from normal (+/+) and athymic nude (-/-) mice, and used as target cells for LPS and Con A stimulation, respectively. Cells $\left(5 \times 10^{5}\right.$ cells $\left./ 200 \mu \mathrm{l}\right)$ were cultured in triplicate in the presence of $5 \mu \mathrm{g}$ of mitogens for $48 \mathrm{~h}$. sensitized mice. IPD-1151T has an ill-defined mode of action, and various elements could account for this protective effect. Functional antagonism towards MCh-induced bronchoconstriction does, however, not account for the findings in the present study, since the $\mathrm{MCh}$ responsiveness in normal control animals is not altered (Fig. 3). It is reported that mouse has airway contractile tissue that responds when exposed to muscarinic agonists such as MCh by the vascular route. ${ }^{23}$ There is also evidence that airway response to muscarinic agonists is presumably

Table 2. Influence of IPD-1151T on in vitro IL-4 production by spleen cells in response to Con A stimulation ${ }^{\mathrm{a}}$

\begin{tabular}{lcc}
\hline $\begin{array}{l}\text { Dose of agent } \\
(\mu \mathrm{g} / \mathrm{ml})\end{array}$ & $\begin{array}{c}\mathrm{IL}-4 \text { content } \\
\text { (mean } \mathrm{pg} / \mathrm{ml} \pm \mathrm{SE})\end{array}$ & $\begin{array}{c}\text { Reduction } \\
(\%)\end{array}$ \\
\hline 0 & $214.7 \pm 10.4$ & \\
5 & $186.9 \pm 27.1^{*}$ & 30.4 \\
10 & $127.9 \pm 16.1^{* *}$ & 40.4 \\
50 & $128.3 \pm 7.9^{* *}$ & 40.2 \\
100 & $109.1 \pm 12.5^{* *}$ & 49.2 \\
500 & $68.2 \pm 12.2^{* *}$ & 68.2 \\
\hline
\end{tabular}

a Spleen cells $\left(5 \times 10^{6}\right.$ cells $\left./ \mathrm{ml}\right)$ prepared from five normal BALB/c mice were cultured with $10 \mu \mathrm{g} / \mathrm{ml}$ Con A for $24 \mathrm{~h}$. IL-4 contents in culture supernatants were assayed by ELISA.

*Not significant $(P>0.05)$ as compared with control, **Significant $(P<0.01)$ as compared with control. 
mediated by specific muscarinic receptor activation. ${ }^{24}$ Therefore, the data in Fig. 3 may be interpreted as showing that IPD-1151T inhibits muscarinic receptor activation that is induced by sensitization with DNP-KLH and results in therapeutic effects on $\mathrm{KLH}-$ induced increase in airway response to MCh.

The importance of IgE-related reactions in terms of their ability to influence airway function has been apparent from clinical and experimental studies. Sensitization of mice by inhalation of allergen caused not only $\operatorname{IgE}$ hyper-production but also increased airway reactivity. ${ }^{4,5}$ Histological examination of the nose and lungs including lower and upper airways prepared from sensitized mice revealed an absence of neutrophils, eosinophils and mast cells at the time of the increased airway hyper-responsiveness. ${ }^{4}$ It is also reported that passively transferred rabbit serum containing allergen-specific $\operatorname{IgE}$ is capable of sensitizing naive rabbits so that they develop airway obstruction, ${ }^{25}$ as well as increased airway hyperresponsiveness after exposure to specific allergen. ${ }^{26,27}$ These reports strongly suggest that alterations in airway function such as hyperresponsiveness to allergens are closely linked to the presence of allergen-specific IgE. The present study revealed the inhibitory effect of IPD-1151T on levels of both total and specific $\operatorname{IgE}$ when the mice were administered orally with the agent (Fig. 6). It is also showed that inhibitory effect of IPD-1151T on $\operatorname{IgE}$ production is due to its suppressive action on B-cell proliferation (Table 1) and IL-4 production from T-cells (Table 2). Taken together, a second possible explanation for the protective effect of IPD-1151T on antigen-induced airway hyper-responsiveness (Fig. 3) would be an effect on $\operatorname{IgE}$ production.

Upon antigenic stimulation, cross-linking of surface $\operatorname{IgE}$ bound to receptors expressed on mast cells and basophils caused secretion of substances stored in granules such as histamine and serotonin, etc. ${ }^{28,29}$ and newly produced physiologically active substances such as leukotrien and platelet activating factor. ${ }^{30,31}$ These chemical mediators are reported to provoke alteration of smooth muscle in airways and result in bronchoconstriction. ${ }^{32,33}$ Matsuura et al. ${ }^{15}$ revealed the inhibitory action of IPD-1151T on degranulation of mast cells in response to antigenic stimulation in vitro. From these observations, there is a possibility that IPD-1151T may function as a membrane stabilizer and attenuate bronchoconstriction induced by MCh and specific antigen.

Since mice administered IPD-1151T for 14 days ( $100 \mathrm{mg} / \mathrm{kg} /$ day) did not show weight loss, ruffled fur and a hunched posture, compared with the control, IPD-1151T could be expected to develop into a new anti-asth matic drug.

ACKNOWLEDGEMENTS. This study was supported in part by Taiho Pharmaceutical Co., Ltd, Tokyo, Japan.

\section{References}

1. Hargreave FE, Ryan G, Thomson NC et al. Bronchial responsiveness to histamine or methacholine in asthma: measurement and clinical significance. J Allergy Clin Im munol 1981: 68:347-55

2. Juniper EF, Frith PA, Hargreave FE. Airway responsiveness to histamine and methacholine: relationship to minimum treatment to control symptoms of asthma. Thorax 1981: 36:575-9

3. Barnes PJ. A new approach to the treatment of asthma. New Eng J Med 1989: 321:1517-27

4. Gorski P, Kolacinska B, Wittczak T. Analysis of the clinical state of patients with occupational asthma following cessation of exposure to allergens. Occup Med (Lond) 1999: 49:285-9

5. Renz H, Smith HR, Honson JE, Ray BS, Irvin CG, Gelfand EW. Aerosolized antigen exposure without adjuvant causes increased $\operatorname{IgE}$ production and increased airway responsiveness in the mouse. J Allergy Clin Im munol 1992: 89:1127-38

6. Larsen GL, Renz H, Loader JE, Bradley KL, Gelfand EW. Airw ay response to electrical field stimulation in sensitized inbred mice. Passive transfer of increased responsiveness with peribronchial lymph nodes. J Clin Invest 1992: 89:747-52

7. Rabe KF, Watson N, Dent G et al. Inhibition of human airway sensitization by a novel monoclonal anti-IgE antibody, 17-9. Am J Respir Crit Care Med 1998: 157:1429-35

8. Dobashi K, Iizuka K, Houjou S et al. Effect of cetirizine on antigeninduced tracheal contraction of passively sensitized guinea pigs. Ann Allergy Asthm a Im munol 1996: 77:310-8

9. Ring J, Bieber T, Vieluf D, Kunz B, Przybilla B. Atopic eczema, langerhans cells and allergy. Int Arch Allergy Appl Im munol 1991: 94:194-201

10. Ra C, Kuromitsu S, Hirose T et al. Soluble human high-affinity receptor for IgE abrogates the IgE-mediated allergic reaction. Int Im munol 1993: 5:47-54

11. Tunon de Lara JM, Okayama Y, Savineau JP, Marthan R. IgE-induced passive sensitization of human isolated bronchi and lung mast cells. Eur Respir J 1995: 8:1861-5

12. Ormstad H, Gaarder PI, Johansen BV, Lovik M. Airborne house dust elicits a local lymph node reaction and has an adjuvant effect on specific IgE production in the mouse. Toxicology 1998: 129:227-36

13. Koda A, Yanagihara Y, Matsuura N. IPD-1151 T: a prototype drug for IgE antibody synthesis modulation. Agents Actions 1991: 34:369-78

14. Matsuura N, Mori H, Nagai H, Koda A. Effect of suplatast tosilate (IPD$1151 \mathrm{~T}$ ) on antibody formations in mice. Folia Pharm Japon [English text] 1992: 100:485-93

15. Matsuura H, Mori H, Nagai H, Koda A. Effect of suplatast tosilate (IPD$1151 \mathrm{~T}$ ) on type I-IV allergic reactions. Folia Pharm Japon [English text] 1992: 100:495-501

16. Konno S, Adachi M, Asano K et al. Suppressive effects of IPD-1151T (suplatast tosilate) on induction of mast cells from normal mouse splenocytes. Eur J Pharmacol 1994: 259:15-20

17. Iijima H, Tamura G, Hsiue TZ, Lin Y, Taniguchi H, Shirato K. Suplatast tosilate inhibits late response and airway inflammation in sensitized guine a pig. Am J Respir Crit Care Med 1999: 160:331-5

18. Oda N, Minoguchi K, Yokoe T et al. Effect of suplatast tosilate (IPD$1151 \mathrm{~T}$ ) on cytikine production by allergen-specific human Th 1 aand Th2 cell lines. Life Scie 1999: 65:763-70

19. Kimata H. Selective enhancement of production of IgE, IgG4 and Th2-cell cytokine during the rebound phenomenon in atopic dermatitis and prevention by suplatast tosilate. Ann Allergy Asthma Immunol 1999: 82:293-5

20. Tsukagoshi H, Nagashima M, Horie T et al. Kimura's disease associated with bronchial asthma presenting eosinophilia and hyperimmunoglobulinemia E which were attenuated by suplatast tosilate (IPD-1151T). Intern Med 1998: 37:1064-7

21. Lee WY, Sehon AH. Suppression of reaginic antibody formation. III. Relationship between immunogenicity and tolerogenicity of haptencarrier conjugate. J Im m unol 1976: 116:1711-8

22. Konno S, Asano K, Kurokawa M, Ikeda K, Okamoto K, Adachi M. Antiasthmatic activity of macrolide antibiotic, roxithromycin analysis of the possible mechanisms in vitro and in vivo. Int Arch Allergy Imm unol 1994: 105:308-16

23. Burden DT, Parkes MW. Effect of $\beta$-adorenoceptive blocking agents on the response to bronchoconstrictor drugs in the guinea-pig air overflow preparation. Br J Pharmacol 1971: 41:122-31

24. Martin TR, Gerard NP, Galli SJ, Drazen M. Pulmonary responses to bronchoconstrictor agonists in the mouse. J Appl Physiol 1988: 64:2318-23

25. Behrens BL, Clark RAF, Marsh W, Larsen GL Modulation of the late asthmatic response by antigen-specific immunoglobulin $\mathrm{G}$ in an animal model. Am Rev Respir Dis 1984: 130:1134-9

26. Marsh WR, Irvin CG, Murphy KR, Behrens BL, Larsen GL. Increases in airway reactivity to histamine and inflammatory cells in bronchoalveolar lavage after the late asthmatic response in an animal model. Am Rev Respir Dis 1985: 131:875-9

27. Murphy KR, Wilson MC, Irvin CG, et al. The requirement for polymorphonuclear leukocytes in the late asthmatic response and heightened airways reactivity in an animal model. Am Rev Respir Dis 1986: 134:62-8 
28. Tung R, Lichitenstein LM. In vitro histamine release from basophils of asthmatic and atopic individuals in D2O. J Immunol 1982: 128:2067-72

29. MacDonald SM, Lichitenstein LM, Proud D et al. Studies of IgEdependent histamine releasing factor: heterogeneity of $\operatorname{IgE}$. I Imm unol 1987: 139:506-12

30. MacGlashan DW, Peters SP, Warner J, Lichitenstein LM. Characterization of human basophil sulfidopeptide leukotriene release: releasability defined as the ability of the basophil to respond to dimeric cross-links. Immunol 1986: 136:2231-9

31. Murray JJ, Tonnel AB, Brash AR et al. Release of prostaglandin D2 into human airways during acute antigen challenge. New Eng J Med 1986: 315:800-4

32. Tanaka DT, Grunstein MM. Effect of substance P on neurally mediated contraction of rabbit airway smooth muscle. J Appl Physiol 1986 60:458-63

33. Bethel RA, Curtis SP, Lien DC et al. Effect of PAF on parasympathetic contraction of canine airways. J Appl Physiol 1989: 66:2629-34

\section{Received 10 March 2000;}

accepted 31 March 2000 


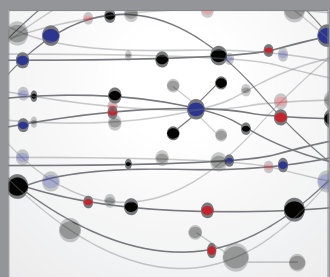

The Scientific World Journal
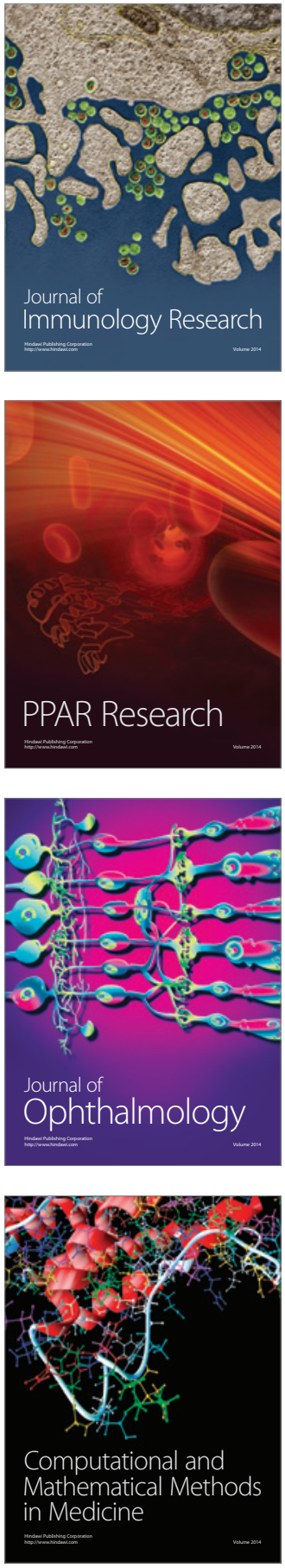

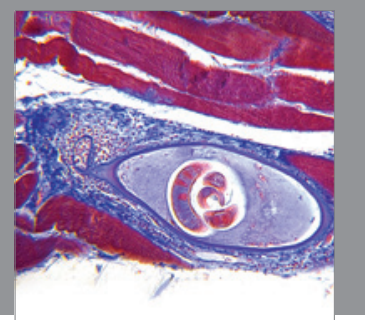

Gastroenterology

Research and Practice
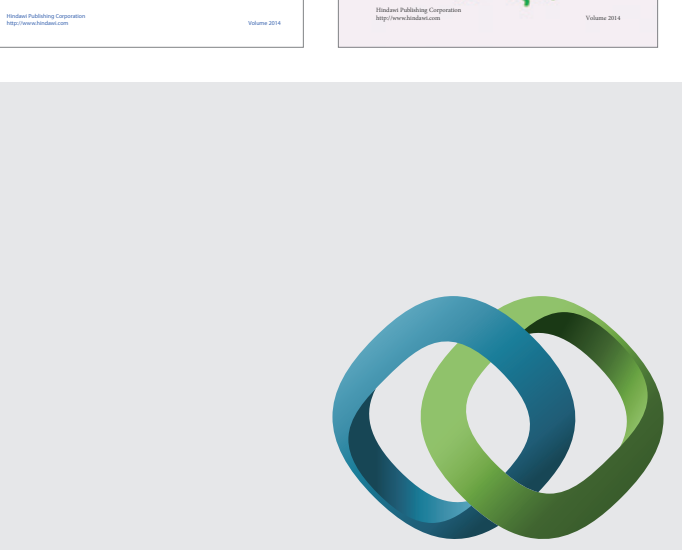

\section{Hindawi}

Submit your manuscripts at

http://www.hindawi.com
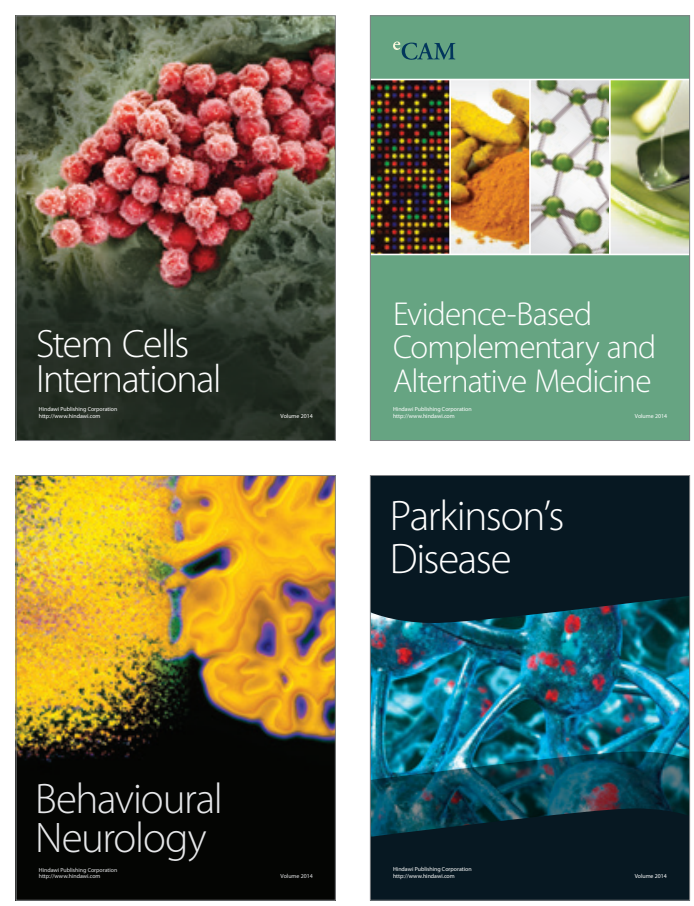

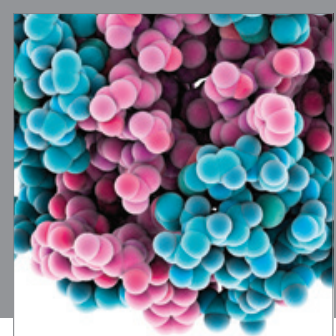

Journal of
Diabetes Research

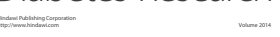

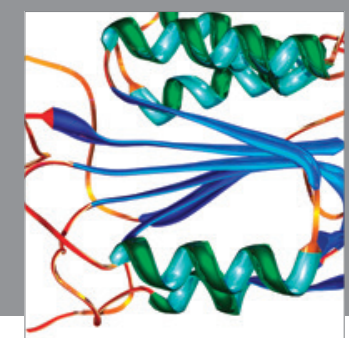

Disease Markers
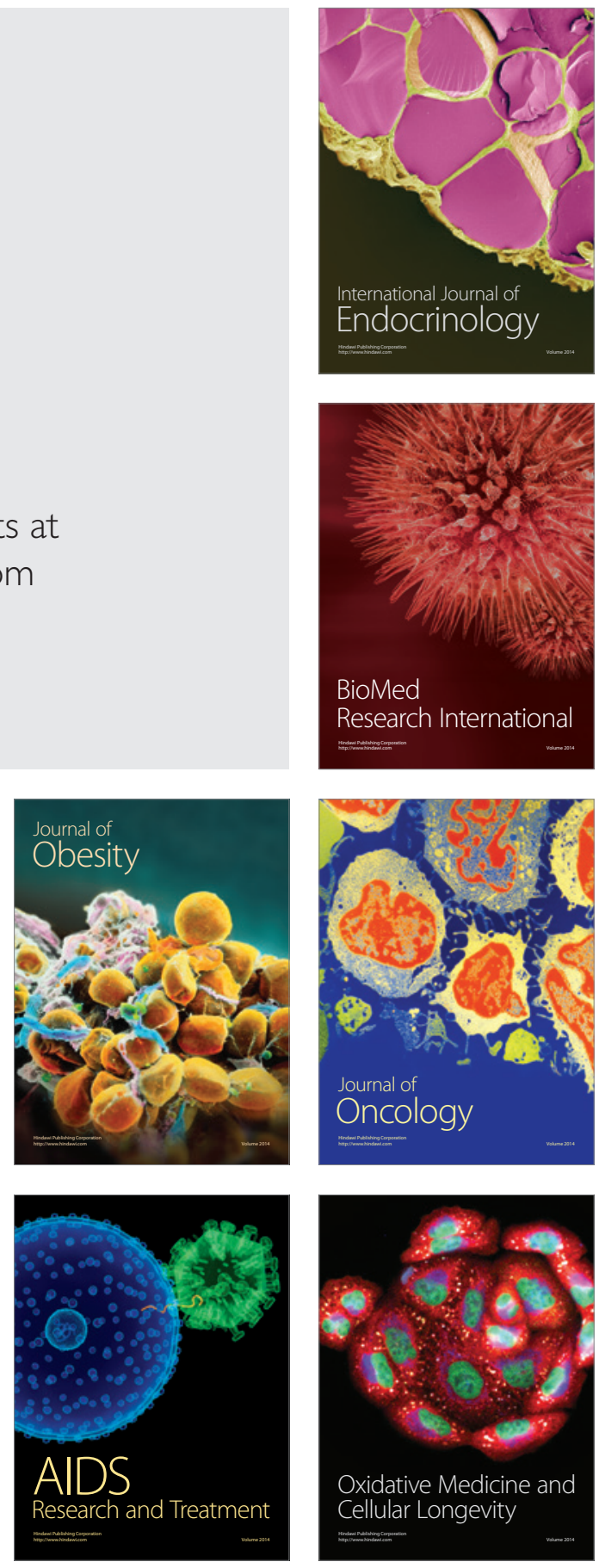